\title{
Assessment of Nurses Knowledge about Health Education to Patients with Brain Tumors Postoperatively
}

\author{
Dr. Shatha Saadi Mohammad *
}

\begin{abstract}
Background and objective: Before, during and after treatment, nurses and allied health professionals should inform and educate patients about the risks and complications of any planned diagnostic test, intervention or treatment. Patients and families should be taught about some of the common side effects of treatment after operation including weight loss, malnutrition, pain, fatigue, and depression. This study aimed to assess nurse's knowledge about health education for patients with brain tumors during their post-operative period.

Materials and Method: descriptive design study was conducted at two teaching hospitals, Neurosurgical hospital and surgical specialties hospital in Baghdad in which craniotomy was performed. Data have been collected by using prepared form, from the period (September $5^{\text {th }} 2012$ to November $5^{\text {th }} 2012.50$ nurses male and female participated in the study.

Results: Most of the convenient sample of the study was females $56 \%$ their educational levels were high institute and college graduate.34\%. The study showed that nurses gender, educational level have a significant association with their abilities of providing of health education about brain tumors postoperatively.

Conclusion: The main result of the study revealed that there were significant associations between nurse's educational level and their knowledge about health education regarding post-operative patients with brain tumors.
\end{abstract}

Keywords: health education, brain tumors, postoperatively.

\section{INTRODUCTION}

Brain tumors (Intracranial tumors) are defined as its all neoplasms arising from the skull, meringues, blood vessels, ductless glands, cranial nerves brain tissue or congenital rests, as well as metastasis tumors, parasitic cysts, granulomas, lymphomas \& tends to cause arise in intracranial pressure (ICP) (Barba, 2002; Lewis et a.1,2004; Brunner and Suddarth,2008).

In some countries the incidence of intracranial tumors is about 5 per 100.000 populations per year. (Walsh and Kakkar, 2001).

While in Iraq according to the Iraqi Cancer Registry Center intracranial tumors accounted about 2/100.000 populations per year having brain tumors from all malignant tumors registered during the period (2005-2010), (Ministry of Health, Iraq cancer registry 2010). Results of Iraq cancer registry (2005-2010), patients with brain tumors need teaching about medication, vitamins, anticonvulsive, corticosteroid \& why they are being given to them.

Also they should be aware of symptoms which were being reported to their physician, such as seizures, changes of level of consciousness, incontinence of urine and or fecal materials (King, 2006).

In (2011) a study showed that patients wanted information about diet, physical therapy and rehabilitation, quick thinking difficulties, fasting, headache, irritability, personality change, fatigue, driving, deep vein thrombosis during the follow up. Although they received health education and booklet, patients needed more information during the 12 months after surgery. This means that monitoring the patient's needs is necessary. From this point these researchers found that nurse's knowledge about health education for brain tumor patient postoperatively is more important than patient information as they are the information provider. (Ozbayir et al., 2011).After treatment, nurses and allied health professionals should inform and educate patients and families about the risks and complications of any planned diagnostic test, intervention or treatment. Patients and families should be taught about some of the common side effects of treatment including weight loss, malnutrition, increased risk of infection, pain, fatigue, and depression. (Pringle

*Instructor/College of Nursing /University of Babylon/E.mail:Shaljabari@yahoo.com 
et al., 1999)

The nurse play an extremely important role in teaching the patient with brain tumors patient \& their families required vast amount of information to understand the necessity of education postoperative in order to maintain health and to avoid complication associated with craniotomy.

The objectives of this study are to assess nurse's knowledge about brain tumors health education postoperative, and to find out the association between nurses knowledge and some variables of socio-demographic characteristics.

\section{MATERIALS AND METHOD}

A descriptive design was conducted at two teaching hospitals: neurosurgical hospital and surgical specialty hospital in Baghdad. A non-probability (purposive) sample which was consisted of (50) nurses who were caring with patients who had craniotomy post-operative was selected for the present study.

Questionnaire was prepared after comprehensive review of related literatures used as a mean of data collection

\section{RESULTS}

Table (1): Frequency distribution of subject according to their socio demographic characteristics:

\begin{tabular}{|l|c|c|}
\hline Characteristics of sample & Freq & \% \\
\hline 1. Gender & 22 & 44 \\
\hline Male & 28 & 56 \\
\hline Female & 13 & 26 \\
\hline 2. Age in years & 15 & 30 \\
\hline $21-25$ & 6 & 12 \\
\hline $26-30$ & 6 & 12 \\
\hline $31-35$ & 6 & 12 \\
\hline $36-40$ & 4 & 8 \\
\hline $41-45$ & &
\end{tabular}

\begin{tabular}{|c|c|c|}
\hline \multicolumn{3}{|l|}{ 3. Educational level } \\
\hline Secondary school graduate & 16 & 32 \\
\hline High institute graduate & 17 & 34 \\
\hline College & 17 & 34 \\
\hline \multicolumn{3}{|c|}{ 4. Years of experience in nursing } \\
\hline Less than 1 year & 1 & 2 \\
\hline $1-5$ years & 18 & 36 \\
\hline $6-10$ years & 6 & 12 \\
\hline $11-15$ years & 6 & 12 \\
\hline More than 16 years & 19 & 38 \\
\hline
\end{tabular}

The data collection was carried out from the period of (September $5^{\text {th }} 2012$ to November $5^{\text {th }} 2012$ ) by using interview all participants by fully aware of the aim and details of the study and reassured that any data pertaining to them deals confidential.

Questionnaire was consisting of two parts: part one include demographical data concerning the responded specific characteristic: gender, age, educational level and years of experience, part two which consisting of twenty questions: extended to health education provided by nurses to the patient with brain tumor post-operative.

To describe and analyze the findings of the study SPSS program was used to analyze the data as a percentage, frequency, $\mathrm{x}^{2}$.the average time required to fill in the questionnaire was $20 \mathrm{~min}$. The reliability of the the questionnaire was determined using person correlation coefficient $(\mathrm{r}=0.83)$ and the face or validity of the questionnaire was determine by presenting the questionnaire to a penal consists of (15) experts.

Table (2): Health education provided by nurses to the patients with brain tumors postoperative:

\begin{tabular}{|c|c|c|c|c|}
\hline \multirow{2}{*}{$\begin{array}{l}\text { Items of nurse knowledge } \\
\text { about brain tumors health } \\
\text { education post-operative }\end{array}$} & \multicolumn{2}{|c|}{ Yes } & \multicolumn{2}{|c|}{ No } \\
\hline & Freq & $\%$ & Freq & $\%$ \\
\hline $\begin{array}{l}\text { 1.Information concerning high } \\
\text { protein and high carbohydrate } \\
\text { diet }\end{array}$ & 35 & 70 & 15 & 30 \\
\hline $\begin{array}{l}\text { 2.Advantage of taking the } \\
\text { prescribed medication } \\
\text { (especially anticonvulsive) }\end{array}$ & 50 & 100 & 0 & 0 \\
\hline $\begin{array}{l}\text { 3.Advantage of visiting the } \\
\text { hospital "follow-up } \\
\text { appointments" }\end{array}$ & 47 & 94 & 3 & 6 \\
\hline $\begin{array}{l}\text { 4.Recognize the signs and } \\
\text { symptoms of infection site of } \\
\text { operation }\end{array}$ & 47 & 94 & 3 & 6 \\
\hline $\begin{array}{l}\text { 5.Avoid driving a car for at } \\
\text { least } 6 \text { weeks }\end{array}$ & 49 & 98 & 1 & 2 \\
\hline $\begin{array}{l}\text { 6.Know the action , side } \\
\text { effects, and scheduling of } \\
\text { medication }\end{array}$ & 49 & 98 & 1 & 2 \\
\hline 7. stop or minimized smoking & 49 & 98 & 1 & 2 \\
\hline $\begin{array}{l}\text { 8.Maintain normal body } \\
\text { weight }\end{array}$ & 40 & 80 & 10 & 20 \\
\hline $\begin{array}{l}\text { 9. Monitor and report sings of } \\
\text { withdrawing, depression. }\end{array}$ & 46 & 92 & 4 & 8 \\
\hline $\begin{array}{l}\text { 10.Information relative to the } \\
\text { importance of taking a lot off } \\
\text { hours of sleep and nabs }\end{array}$ & 44 & 88 & 6 & 12 \\
\hline
\end{tabular}


Table (3): the association between the nurse's gender and their abilities of providing knowledge about health education for brain tumors patients postoperatively.

\begin{tabular}{|l|c|c|c|}
\hline \multirow{2}{*}{ Nurses knowledge gender } & Yes & No & \multirow{2}{*}{ Total } \\
\cline { 2 - 3 } & Ferq. & Ferq. & To \\
\hline Male & 202 & 62 & 264 \\
\hline Female & 202 & 34 & 236 \\
\hline Total & 404 & 96 & 500 \\
\hline
\end{tabular}

$\mathrm{X}^{2}$ obs. $22.85 \mathrm{df}=1 \mathrm{x}^{2}$ critical $3.841 \mathrm{p}<0.05$

Table (4): the association between the nurse's educational levels and their abilities of providing knowledge about health education for brain tumors panties postoperatively.

\begin{tabular}{|l|c|c|c|}
\hline $\begin{array}{l}\text { Nurses knowledge } \\
\text { Educational level }\end{array}$ & Yes & No & \\
\cline { 2 - 3 } & Ferq. & Freq. & Total \\
\hline $\begin{array}{l}\text { Secondary school } \\
\text { graduate }\end{array}$ & 46 & 12 & 221 \\
\hline High institute graduate & 208 & 13 & 211 \\
\hline College & 170 & 51 & 68 \\
\hline Total & 424 & 76 & 500 \\
\hline
\end{tabular}

\section{DISCUSSION}

The data analysis had revealed that $56 \%$ of the nurses were females and the remaining were males, most of them were 26-30 years old Table (1).

Relative to their educational status, those who were high institute graduate and college accounted for $34 \%$. While the remaining were secondary school graduate $(32 \%)$.

Table (2) shows that most of the nurses $(70 \%)$ had knowledge concerning high protein, carbohydrate and they provide it to patients with brain tumors.

The nurses should know that the diet of those patients must be low in fats and high in carbohydrates and protein, and sometimes the patients them self usually refuse to eat fatty foods because of the nausea that follows (Zhou et al, 2010) .

Relative to the statement about the advantages of taking the prescribed medication (especially anticonvulsive) one hindered percent $(100 \%)$ of the nurses provided health education about this item. The patient should know what medication are required (antibiotics, anticonvulsive, sedatives) and why they are given (Palese et al, 2012)

The American Cancer Society (2006) showed that the most important nursing intervention during treatment is for the nurse to be well educated regarding the medication(s) the patient is to receive. Control and management of side effects is crucial during the administration of medications.

Concerning the advantages of visiting the hospital follow up appointment and recognize the sign and symptoms of infection it was found that equal number of nurses who had this knowledge and they provided it were accounted $94 \%$ of the sample.

Neurosurgical nurses tended to overestimate patients' problems, and might warrant a different approach to caring for patients with brain tumors, whose problems are overestimated less. They know how to convene patients with their problems and how to deal with it (Palese et al, 2012).

In regard to item (5) which was concerned with avoid driving a car for at least 6 weeks the result indicated that there was $98 \%$ of the sample had such information. It was stated that the nurse is responsible for explaining and instructing the patients to avoid driving a car for at least 6 weeks. And this comes along with the many studies which revealed that driving a car has many hazards for patients after craniotomy because they lack concentration while driving.

The study results indicated also that equal number of nurses had provided health education about action, side effect, scheduling of medication and stop or minimized smoking that were accounted for $98 \%$ of the staff nurses. Gill and Duffy (2010) pointed that the postoperative teaching goals instructions to the patients and family should include stop smoking, and know how to deal with the action, side effect and scheduling of medication.

The results also indicated there was only $80 \%$ of the sample who had information and instruction and given to the patients concerning maintain normal body weight.

Regarding the monitor report of withdrawing and depression, and the importance of taking a lot off hours of sleep and nabs in the same table the percentage revealed that $92 \%, 88 \%$ on sequence.

Table (3) and (4) revealed that there were significant associations between the nurse's gender, level of education and their abilities of providing knowledge for brain tumors patients postoperatively. International research has shown that specialist neurosurgical nurses make a considerable difference to physical and psychosocial patient care. It is therefore paramount that non-specialty nurses' educational needs are met to develop clinical competence and to provide supportive holistic care for both patients and their families. 


\section{CONCLUSIONS}

According to the finding of the present study, most of the convenient samples of the study were females, within age group (26-30) years; their educational levels were high institute, and college graduate.

Most of the sample had knowledge about brain tumors. In addition to that the study showed that nurses gender, educational level have a significant association with their abilities of providing of health education about brain tumors postoperatively.

\section{RECOMMENDATION}

Depending on the findings and conclusions of the study, the researcher recommended the following: present the nurses with a high standard of scientific booklet on health education about brain tumors postoperative. Further study should be done on large sample. Give a refresh course for nurses according to the teaching advance in management of patient care. Enhance or increase numbers of females of the nursing profession by many social and put on plan to boost support and service for females to work in nursing.

\section{REFERENCES}

American Cancer Society.(2006). What are brain and spinal tumors?. Retrieved from: http://www.cancer.org/docroot/ cri/ content/cr on 2nd January, 2011.

Brunner, LS.; \& Suddarth, P. (2008). Text book of Medical Surgical Nursing. (5th ed.). J.B.Lippincott Company, Philadelphia. P.p. 56.
Gill, F.; \& Duffy A. (2010). Caring for cancer patients on non-specialist wards. Br.J Nurs. 19(12). P.p.761.

King, C.R. (2006). Advances in how clinical nurses can evaluate and improve quality of life for individuals with cancer. Oncology Nurse Forum Jan. 33(1 Suppl). P.p. 5-12.

Lewis, S.; Heitkemper, Dirksen D. (2004). Medical Surgical Nursing. (5th ed.). Mosby Com. P.p. 60-66

Ministry of Health. (2010). Results of Iraq cancer registry (2005-2010). Baghdad. P.p. 107.

Ozbayir, T; Malak, AT; Bektas, M; Ilce, AO; Celik, GO.(2011). Information needs of patients with meningioma. Asian Pac $J$ Cancer Prev.12 (2). P.p. 439-41.

Palese, A.; Romano, A.; Moreale, R.; Magee, J. (2012). Do nurses risk underestimating the problems of patients with frontal lobe neoplasms?. Eur J Oncol Nurs. 16(2). P.p.158-6.

Pringle, A.M.; Taylor, R.; \& Whittle, I.R. (1999). Anxiety and depression in patients with an intracranial neoplasm before and after tumors surgery. $\mathrm{Br} J$ Neurosurg. 13. P.p.46-51.

Walsh, D. \& Kakkar, A. (2001). Thromboembolism in brain tumors. Critical care neurology and neurosurgery. 7 (5). P.p. 326-33.

Zhou, G.; Stoltzfus, JC.; Houldin, AD.; Parks, SM.; Swan, BA.(2010). Knowledge, attitudes, and practice behaviors of oncology advanced practice nurses regarding advanced care planning for patients with cancer. Oncol Nurs Forum. 37(6). P.p. 400-10. 